\title{
Sprawozdanie z VII Ogólnopolskiej Konferencji Naukowej "Miejsce Innego we współczesnych naukach o wychowaniu. Krytyczna analiza", Obrzycko, 15-16.04.2015 r.
}

W dniach 15-16 kwietnia 2015 r. już po raz siódmy odbyła się Ogólnopolska Konferencja Naukowa z cyklu „Miejsce Innego we współczesnych naukach o wychowaniu" organizowana przez Zakład Specjalnych Potrzeb Edukacyjnych UAM w Poznaniu pod patronatem Komitetu Nauk Pedagogicznych Polskiej Akademii Nauk. Motywem przewodnim tegorocznej edycji była „krytyczna analiza”. Na dwa dni Dom Pracy Twórczej w Obrzycku stał się miejscem wymiany myśli i doświadczeń badaczy z całej Polski związanych z pedagogiką specjalną.

Konferencję otworzyła przewodnicząca komitetu naukowego konferencji prof. dr hab. Iwona Chrzanowska, wyrażając nadzieję, iż obrady będą wartościowe i owocne. Pierwszą sesję plenarną prowadzili: dr hab. Beata Jachimczak oraz dr hab. Grzegorz Szumski. Rozpoczął ją prof. dr hab. Amadeusz Krause. Jego wystąpienie było dobrym wstępem w tematykę konferencji, ponieważ profesor odniósł się do węzłowych problemów pedagogiki specjalnej. Skupił się przede wszystkim na problemach związanych z trudnościami w realizacji założeń edukacji włączającej. Prof. dr hab. Zenon Gajdzica odwołał się do koncepcji pedagogiki długu jako czynnika współkreującego jakość edukacji uczniów z niepełnosprawnością w szkole ogólnodostępnej. To nowatorskie spojrzenie na problem edukacji włączającej wywołało ożywioną dyskusję wśród słuchaczy. Następnie wystąpiła dr hab. Teresa Żółkowska, prezentując referat pt. „Post/humanizm. Nie- 
pełno/sprawność" odnoszący się do kwestii postrzegania osób z niepełnosprawnością w społeczeństwie. Kwestie społeczne poruszone zostały również w referacie autorstwa dr. hab. Piotra Łukowskiego. Dotyczył on granfalonu, a zwłaszcza jego grupy zewnętrznej, czyli zjawiska celowego kreowania grupy osób skazanych na bycie znienawidzonymi. Następnie dr hab. Ewa Muszyńska poruszyła problem „Inności” w klasie szkolnej. Był on kontynuowany także podczas II sesji plenarnej, którą zgodziła się prowadzić wraz z dr hab. Teresą Żółkowską. Dr hab. Jolanta Szempruch podjęła kwestię funkcjonowania nauczyciela i ucznia w klasie szkolnej. W tym wypadku „inność" rozumiana była jako przynależność do innej grupy kulturowej. Kolejne wystąpienie, którego autorką była pani dr hab. Danuta Kopeć, dotyczyło przyczyn oraz przejawów urazu przywiązaniowego u osoby z niepełnosprawnością. Kolejna prelegentka - dr hab. Sławomira Sadowska odniosła się do kwestii wartości w nauczaniu. Wygłosiła referat pt. „Wartości w sferze kształcenia osób z niepełnosprawnością: kwestie moralnego minimum i moralnego maksimum". Pani dr hab. Hanna Żuraw w swoim wystąpieniu poruszyła temat twórczości rozpatrywanej w wielu jej wymiarach, których synteza stanowić może przesłankę do poszukiwania alternatywnego paradygmatu rehabilitacji osób z niepełnosprawnością. Ostatni referat przed dyskusją wygłosiła dr hab. Zdzisława Janiszewska-Nieścioruk. Dotyczył on dość kontrowersyjnego tematu „Wykluczających praktyk inkluzji społecznej osób z niepełnosprawnością". Wystąpienie to otworzyło ożywioną dyskusję nad kondycją edukacji włączającej w Polsce.

Trzecia, ostania tego dnia sesja poświęcona została wystąpieniom młodych naukowców, którym organizatorzy tegorocznej konferencji postanowili poświęcić szczególną uwagę. Każdy z prelegentów wcześniej wyznaczył swojego opiekuna naukowego, który zobowiązany został do przeprowadzenia ewaluacji wystąpienia pod kątem merytorycznym oraz metodologicznym. Role opiekunów naukowych zgodzili się podjąć prof. dr hab. Iwona Chrzanowska, prof. dr hab. Zenon Gajdzica, dr hab. Beata Jachimczak, prof. dr hab. Amadeusz Krause oraz dr hab. Grzegorz Szumski. Sesję otworzyło niezwykle ciekawe wystąpienie prof. Bogusława Śliwerskiego na temat współczesnej socjalizacji do terroryzmu. Prof. wskazał w nim na problemy, które może implikować wszechobecna „kultura przemocy". Następnie odbyły się prelekcje młodych naukowców. Rozpoczęła je mgr Magdalena Świgost referatem pt. „Jednostka zagrożona społeczną stygmatyzacją $\mathrm{w}$ relacjach interpersonalnych - wybrane kategorie 
analiz", który stanowił raport z badań prowadzonych w ramach jej pracy doktorskiej pt. "Autopercepcja i percepcja społeczna osób z wybranych grup zagrożonych stygmatyzacją. Perspektywa pedagogiczna”. Magdalena Świgost skupiła się na problemie dystansu społecznego wobec wybranych grup zagrożonych stygmatyzacją oraz na podstawowych czynnikach wzmacniających lub obniżających jego poziom. Kolejną prelegentką była mgr Barbara Tokarska. Przedstawiła swoje wynika badań prowadzonych wśród terapeutów pracujących metodą społeczności terapeutycznej z osobami uzależnionymi od narkotyków. Następnie dr Agnieszka Wołowicz-Ruszkowska zaprezentowała wyniki badań jakościowych prowadzonych wśród kobiet z niepełnosprawnością, dotyczących ich doświadczeń związanych z macierzyństwem. Czwarte wystąpienie poruszało zagadnienie rozwijania umiejętności społecznych dzieci przedszkolnych uczestniczących w programie "Play Time/Social Time”. Przedstawiła je dr Joanna Smogorzewska, a wyniki jej badań stanowiły podsumowanie rocznego projektu edukacyjno-badawczego. Jako kolejne zaprezentowały się dr Izabella Kucharczyk oraz dr Agnieszka Dłużniewska. Ich referat, również będący komunikatem z badań, był zatytułowany „Ja jako Inny - wyznaczanie celów edukacyjnych i społecznych prze uczniów ze specyficznymi trudnościami w uczeniu się". Kolejny referat, autorstwa mgr Anny Irasiak, prezentował badania osadzone w paradygmacie jakościowym. Materiałem badawczym były $\mathrm{w}$ tym przypadku obserwacje zajęć edukacyjnych $\mathrm{z}$ zakresy języka migowego prowadzone przez osoby głuche. Ostatnią prelegentką była mgr Katarzyna Smoter, która przedstawiła propozycję zastosowania portalu społecznościowego Facebook do realizacji celów edukacji antydyskryminacyjnej. Dyskusja, która wywiązała się po wysłuchaniu wszystkich wystąpień, dotyczyła zarówno kwestii merytorycznych, jak i metodologii przeprowadzonych badań. Wyznaczeni opiekunowie naukowi bardzo dobrze wywiązali się ze swoich ról, dzieląc się z prelegentkami wnikliwymi uwagami, które niewątpliwie zainspirują je do doskonalenia swojego warsztatu badawczego. Ta forma okazała się bardzo dobrą płaszczyzną wymiany poglądów pomiędzy młodymi oraz bardziej doświadczonymi naukowcami. Dzień uwieńczyła uroczysta kolacja, która odbyła się w podziemiach pałacu.

Drugi dzień obrad został podzielony na sekcje tematyczne oraz jedną podsumowującą sesję plenarną. Tematem przewodnim pierwszej sekcji był "Inny w percepcji społecznej", a prowadziła ją dr hab. Beata Jachimczak. Znalazły się w niej następujące referaty: 
- „Podobny w inności i inny w podobieństwie - rzecz o spotkaniu innego w ujęciu Józefa Tischnera", dr Inga Mizdrak;

- „Beka z nienormalsów”, czyli satyryczny obraz niepełnosprawnych we współczesnej kulturze masowej", dr Przemysław Grzybowski;

- „Rola czasopisma «Szkoła Specjalna» w kształtowaniu wizerunku społecznego dziecka $\mathrm{z}$ niepełnosprawnością $\mathrm{w}$ okresie międzywojennym (1924-1939)", dr Danuta Apanel;

- „Kategoria ciała w sytuacji niepełnosprawności i spotkania z Innym", dr Joanna Belzyt;

- „Niewidomy jako Inny? - spostrzeganie osób niewidomych przez młodzież licealną", dr Kornelia Czerwińska;

- Seksualność osób z niepełnosprawnością intelektualną w dyskursie pedagogów specjalnych - pomiędzy autonomią a zależnością", mgr Marta Jurczyk;

- „(Czy)twórcza obecność osób niepełnosprawnych w przestrzeni publicznej", dr Edyta Nieduziak;

- „Jakość życia osób z autyzmem i ich rodzin w społeczeństwie XXI wieku. Literackie ujęcie biograficzne", mgr Agnieszka Sokołowska-Kasperiuk;

- „Wizerunek publiczny Innego. Przełamywanie stereotypów na temat Romów w kampaniach społecznych", dr Łukasz Kwadrans;

- „Sztuka jako droga włączania osób z niepełnosprawnością intelektualną do społeczeństwa", mgr Sabina Pawlik.

Kolejna sekcja została poświęcona tematowi "Inny jako dorosły” i podejmowała różnorodne tematy związane $\mathrm{z}$ dorastaniem i dorosłością osób obarczonych różnego rodzaju „innością" - od niepełnosprawności do odmienności ze względu na wiek czy chorobę psychiczną. Prowadziła ją dr hab. Bernadeta Szczupał. Poruszono w niej następujące tematy:

- „Dorosłość osób z umiarkowaną i znaczną niepełnosprawnością intelektualną w kontekście biograficznego aspektu tożsamości", dr Beata Tylewska-Nowak;

- „(Nie)pełnosprawna starość - przyczyny, uwarunkowania, wsparcie", dr Anna Gutowska;

- „Praca jako czynnik budujący tożsamość Innego (wobec drugiego niepełnosprawnego)", dr Irena Ramik-Mażewska;

- „Wizje dorosłości i starości młodzieży z niepełnosprawnością intelektualną", mgr Kamila Skowrońska;

- „Zredukowana dorosłość osób z głęboką niepełnosprawnością intelektualną w domu pomocy społecznej", mgr Dorota Prysak; 
- „Niepełnosprawność - przeszkoda w studiowaniu”, dr Magdalena Bełza;

- „Między średnią a późną dorosłością - prewencyjna funkcja zajęć dla "seniorów 50+»", mgr Julia Sienkiewicz-Wilowska;

- „Przejawy psychopatyczności u młodych dorosłych”, mgr Karolina Kaliszewska;

- „Miejsce Innego w ekonomii społecznej - na przykładzie Kujawsko-Pomorskiego Centrum Ekonomii Społecznej", dr Maciej Jabłoński;

- „Relacje interpersonalne w życiu młodych dorosłych z zaburzeniami ze spektrum autyzmu - analiza jakościowa”, mgr Lidia Szmania.

Trzecia sekcja zatytułowana była „Inny jako podmiot oddziaływań edukacyjno-terapeutycznych". Przewodniczył jej dr hab. Jarosław Bąbka. Podczas tej sekcji wygłoszone zostały następujące referaty:

- „Rodzice wobec aktywności on-line swoich dzieci z niepełnosprawnością intelektualną", dr Piotr Plichta;

- "Rodzice uczniów kształcących się w klasach integracyjnych - ich motywy, oczekiwania i ocena pracy nauczyciela", mgr Dominika Przybyszewska;

- „Zachowania ryzykowne młodzieży z niepełnosprawnością", dr Jolanta Lipińska-Lokś;

- „Właściwości nauczycieli klas integracyjnych a relacje rówieśnicze w klasie", mgr Matylda Pachowicz;

- „Funkcjonowanie dzieci i młodzieży z niepełnosprawnością w różnym wieku - projekt międzyresortowego modelu przygotowania do pełnienia różnych ról społecznych", dr Teresa Serafin;

- „Inne emocje - poznawcza reprezentacja emocji dziecka z lekką niepełnosprawnością intelektualną", dr Marzena Buchnat. Referat został przygotowany razem z dr hab. Aleksandrą Jasielską;

- „Terapia dydaktyczna a rozpoznawanie potrzeb edukacyjnych i wychowawczych ucznia", dr Barbara Trochimiak;

- "Możliwości komunikacyjne dziecka z zespołem Aspergera”, dr Iwona Konieczna;

- „Problemy diagnozy małego dziecka pod kątem zaburzeń ze spektrum autyzmu", dr Aneta Wojciechowska;

- „Inny bo uzdolniony czy opóźniony?”, dr Teresa Wejner-Jaworska;

- „Władza symboliczna terapeutów osób autystycznych”, mgr Joanna Buława-Halasz; 
- „Efektywność terapii dziecka z autyzmem od terapii behawioralnej do interdyscyplinarnej terapii humanistycznej - dylematy wyboru", mgr Malwina Zawieja;

- „Muzykoterapia i jej właściwości w usprawnianiu dziecka autystycznego. Projekt badania własnego", mgr Sara Knapik-Szweda;

- „Pisanie wierszy jako sposób radzenia sobie z moratorium psychospołecznym przez osobę z uszkodzonym wzrokiem. (Krytyczna)analiza dyskursu”, dr Małgorzata Oleniacz;

- „Rola i miejsce «terapeuty-cienia» w procesie terapii oraz wspomagania edukacji dziecka z autyzmem w przedszkolu ogólnodostępnym", mgr Aleksandra Antonik.

Ostatnia sesja plenarna konferencji objęła pięć referatów. Jako pierwszy wystąpił prof. Jaroslav Balvin. Mówił o „inności” społeczności romskiej oraz problemach, z jakimi się ona obecnie boryka. Następnie dr hab. Marcin Wlazło zarysował bardzo aktualne problemy kształtującej się coraz wyraźniej klasy społecznej "prekariuszy” oraz towarzyszącej jej tymczasowości i niepewności edukacji, rehabilitacji, pracy i życia - tym razem w kontekście niepełnosprawności. Dr hab. Jarosław Bąbka wygłosił referat zatytułowany „Kształtowanie się tożsamości osób z niepełnosprawnością jako zadanie rozwojowe”. Podczas ostatniego wystąpienia dr hab. Bernadeta Szczupał podjęła wątek godności osób starszych w świetle koncepcji praw człowieka. Przeanalizowała wiele istotnych dokumentów wyznaczających perspektywę interpretacji prawa w zakresie kwestii dotyczących osób w wieku podeszłym, w tym z niepełnosprawnością.

Po zakończeniu ostatniej sesji nastąpiło podsumowanie obrad w sekcjach tematycznych oraz zamknięcie obrad. Przewodnicząca komitetu naukowego prof. dr hab. Iwona Chrzanowska podziękowała wszystkim uczestnikom za zaangażowanie i udział w dyskusjach oraz wyraziła nadzieję na spotkanie podczas VIII Konferencji „Miejsce Innego we współczesnych naukach o wychowaniu". 